\title{
Marx og det moderne
}

\author{
Hans-Jørgen Schanz.
}

»Troen på fremskridtet, på en uendelig perfektibilitet - en uendelig opgave i moralen - og forestillingen om den evige genkomst er komplementare. De er de uopløselige antinomier, i forhold til hvilke det dialektiske begreb for den historiske tid skal udvikles. Overfor dette begreb forekommer forestillingen om den evige genkomst som netop den 'platte rationalisme', som fremskridtstroen har bragt i vanry, og denne sidste lige så vel tilhørende den mytiske tankemåde som forestillingen om den evige genkomst $\ll$.

Walter Benjamin

\section{I}

Et sted i »Grundrisse« (pg. 387-88) siger Marx i forbindelse med en kontrastering af rigdomsbetragtninger i prækapitalistiske formationer og så rigdommens form under kapitalistisk-transitoriske betingelser:

$\gg$ I den borgerlige $\emptyset$ konomi - og i den produktionsepoke, der modsvarer den - fremtræder denne fuldstændige udarbejdelse af det menneskelige indre som fuldstændig udtømning, denne universelle genstandsmæssiggørelse som total fremmedgørelse, og nedrivningen af alle bestemte, ensidige formål som opofrelsen af formålet i sig selv under et helt ydre formål. Derfor forekommer på den ene side den barnlige, gamle verden som den højeste. På den anden side er den det $\mathrm{i}$ alle de forhold, hvor der søges lukket gestalt, form og given begrænsning. Den er tilfredsstillelse på et bornert standpunkt; medens det moderne synes utilfredsstillet, eller: hvor det optræder tilfredsstillet i sig, der er det gement«.

Citatet skal i første omgang stå ukommenteret som belæg for, at modernitetsproblematikken er alt andet end fraværende hos Marx. Stedet er skrevet 1858, altså omtrent samtidigt med at Flaubert udgav »Madame Bovary « og Baudelaire »Les Fleurs du Mal «. Som bekendt var det Baudelaire, der formulerede de centrale ansatser til en teori om det æstetisk moderne, som blev grundliggende for modernismen. Det er i øvrigt samtidigt med, at det i sin intention kosmopolitiske varehus - verdensudstillingerne - iscenesætter produktionens og konsumtionens megalomani. Det sker i en tid, hvor denne endnu ikke var sivet ned i hverdagens porer og eufemistisk talt blevet til trivialitet: 
»Verdensudstillingerne stiller varerne i et forklarelsens skær. De skaffer en ramme, i hvilken deres brugsværdi træder tilbage. De åbner et phantasmagori, som mennesket træder ind i for at lade sig afsprede. Underholdningsindustrien gør dette lettere for mennesket, idet den hæver mennesket op på niveau med varen. Det overlader sig til deres manipulationer, idet det nyder sin fremmedgørelse fra sig selv og de andre « (Benjamin, »Das Passagen-Werk «, s. 50).

Forsøget her er kaldt »Marx og det moderne« - og det implicerer at man vover pelsen i mere end en forstand. For det første: hvad er det moderne, hvis ikke netop dét, som ikke lader sig definere, fordi det er transitorisk, flygtigt, strømmende? - som Baudelaire sagde. For det andet: Hvilken art modernitetsproblematik udtaler den Marxske teori? Et sådant spørgsmål udløser i det mindste to nye: hvad menes der i præciserende forstand med den Marxske teori og på hvilken måde, om overhovedet, tematiserer den det moderne? For det tredje kunne titlen være en provokation i forhold til meget kontemporære positioner - i det mindste i det omfang, disse for en stund suspenderede den selvforblændende brug af fetichordet post-moderne. Og endelig - for det fjerde - kunne man med en sådan titel let vække den ikke forlods angribelige mistanke, at dette er endnu et af forsøgene på at modernisere Marx på en helt igennem udvendig maner. Altså en maner, hvor man udstyrer den Marxske teori med flere og flere hjælpekrykker, så den ikke åbenlyst remtræder som det, den da måtte være, nemlig i bund og grund forældet ved sin mangelfuldhed, samtidig med at netop denne moderniseringssminke tjener til at skjule, hvor lidt moderne, den Marxske tænkning egentlig var.

Uden at det skal tjene til immuniseringspansring er det dog nødvendigt at gøre rede for et par forhold: det følgende er oprindeligt fremlagt som foredrag. Der vil være spring i argumentationen, og det meste har karakter af at være overvejelser, der måske i højere grad skulle have været modnet igennem refleksionsarbejde end der har været tid til - hvilket man så kan henføre til de moderne produktionsbetingelser for intellektuelt arbejde.

II

Modernitetsproblematikken eller modernitetsdiskussionen har en lang historie, der starter i den tidlige middelalder, løber ind over højmiddelalderen og får betydning i renaissancen for så senere at blive et krystallisationstema i oplysningstænkningen. Her efter udspilles en ny fase i romantikken, der foregriber eller måske endog grundlægger diskussionen om det æstetisk og historisk moderne, som eksplicit udtales og tematiseres omkring midten af det nittende århundrede. I dag lever modernitetsdiskussionen i bedste velgående i forsøgene på at pointere det post-moderne. Det kan tilføjes, at det hører med til stort set hele modernitetsdiskussionen lige fra starten, at den med hyppige mellemrum munder ud i konklusive udtalelser så som: det moderne eksisterer ikke længere. Afsværgelsen af det moderne er ingenlunde noget, 
som postmoderne positioner har patent på, men minder måske netop ved sin lede ved det uforløste i det moderne om dettes fortsatte eksistens. Måske var det rigtigt som Marx skrev, at det moderne

»lader utilfredsstillet, eller: hvor det optræder tilfredsstillet i sig, der er det gement $\ll$.

Men er den dødsmaske, som det postmoderne ynder at udstille som sin fredsslutning med det moderne egentlig mindre »gemein «? Der er hidtil først og fremmest talt om »det moderne«. Altså en substantivering, hvor der tilsyneladende udsiges noget om det moderne som sådant til forskel fra talen om »de moderne samfund «, »den moderne kunst «, »den moderne stil«, »de moderne tider « osv., hvor udtrykket »moderne « anvendes prædikativt. Det hører imidlertid med til modernitetsdiskussionens udviklingshistorie, at der lidt efter lidt sker et skifte derved, at medens man i starten og adskillige århundreder frem altid anvender udtrykket som prædikat, så begynder selve substantivet »det moderne « efterhånden at vinde indpas. Før dette skifte kan man dog også støde på udtryk, hvor der tales om »det moderne«, men da er det betegnende nok altid underforstået, at der er tale om noget ganske bestemt, som regel kunsten; og det er aldrig underforstået, at det drejer sig om det moderne som sådant. Med romantikken er det afgørende skifte ved at være indarbejdet. Og som vist, er det terminologisk indarbejdet hos Marx.

Måske kan Marx give en forklaring på denne ændring i udtrykkets udviklingshistorie. Følger man hans refleksioner omkring arbejdsbegrebets udviklingshistorie, som disse f.eks. kommer frem i »Einleitung « til »Grundrisse «, er man sandsynligvis på rette spor. Her hedder det (pg. 25):

»Således opstår de mest almene abstraktioner overhovedet kun ved den rigeste, konkrete udvikling, hvor ét fremtræder fælles for meget, fælles for alt. Så kan det ikke længere kun tænkes i en særlig form«.

Det er således først i forbindelse med en konkretiserende udvikling - og det vil hegeliansk sige en differentierende udvikling - hvor flere og flere processer og fænomener antager karakter af at være under indflydelse af et og samme, her »moderniteten«, at det almene udtryk »det moderne « kan udtales. Opkomsten af udtrykket »det moderne « er selv et produkt af og i den moderne historie. Og man kan sikkert følge Marx et skridt længere omkring dette punkt. Hvad der hidtil er fremstillet er momenter til en forklaring på udtrykkets genese. Dets gyldighed er sikkert, om end ikke reducerbar til genesen, så dog så meget reflekteret i den, at udtrykket »det moderne « ikke alene først kan udtales, men også først får gyldighed i og for den nyere historie. Et udtryk som »det moderne i antikken« vil i konsekvens heraf være 
en indholdsmæssig meningsløshed, selv om det måske ikke formelt er en absurditet. Marx udtrykte denne genese-gyldighedsfigur omkring arbejdet, og sagde:

»Dette eksempel ... viser slående, hvorledes selv de mest abstrakte kategorier-på trods af, at de netop på grund af deres abstrakte karakter er gyldige for alle epoker alligevel i denne abstraktions bestemthed er produktet af historiske forhold og kun besidder deres fulde gyldighed for og indenfor disse forhold« (Gr., s. 25).

Skulle man stikordsagtigt kort angive momenter i den sociokulturelle baggrund for udtrykket »det modernes « fremkomst, så måtte man uden tvivl pege på opkomsten af en erfaringsverden med tiltagende rumslig kompleksitet og interdependens, hvor temporalitetsstrukturer ikke bare er medorganiserende for, men selv optrædende i erfaringsdannelsen. Og denne nye erfaringsverdens grundimpuls måtte da antages at være konsekvensmæssigt forbundet med ændringen i de historisk indstiftede afhængighedsformer. Tesen - der i øvrigt ikke her skal udfoldes mere - bag ovenstående overvejelse er denne, at erfaringens struktur grundlæggende antages at være reflekteret i de historisk indstiftede og historisk variante former for afhængighed.

\section{III}

I følge Hans Ulrich Gumbrecht (»Geschichtliche Grundbegriffe, pg. 93-131) kan der definitorisk ekstraheres tre grundbetydninger, som ordet »moderne « har haft i modernitetsdiskussionen:

1) Det moderne er en deskriptiv betegnelse for et skel mellem det samtidige og det forgangne.

2) Det moderne angiver en epokalitetsbestemmelse med et normativt (positivt eller negativt) indhold og udtrykker den kontrasterende vurdering af forholdet mellem noget nyt og noget gammelt.

3) Det moderne er udtrykket for det forbigående, flygtige og transitoriske, der alene lader sig bestemme i forhold til noget som er ikke-tilblivende eller tilblevet, men evigt. Det rummer ikke i sig selv en sådan grad af homogenitet eller fastfrosset kvalitet, at det lader sig identificere via kontrasten til det forgangne som noget tilblevet. Ligeledes opereres der her med en opfattelse af samtiden som en mulig fremtids fortid, hvilket medfører, at det forgangne selv opfattes som eventuelt havende været moderne, og derfor opløses også det forgangne som homogen størrelse.

Gumbrecht er især under indflydelse af Hans Robert Jauss, hvad angår modernitetsproblematikken i det æstetiske og Reinhart Koselleck hvad angår det historieteoretiske. Overvejelserne i denne her artikel -der anvender Gumbrechts skema - er inspireret bl.a. af Jauss, Koselleck, Benjamin, Adorno, Henri Lefebvre, Wendorf, Habermas, Lepenies og Marx. 
Det moderne er - i de konnotationer, der her arbejdes med - altså også en temporalitetsbestemmelse, en samtidskvalificering, der enten kan være deskriptiv, normativ (og da forbinde sig med et dekadence- eller et progresskema) eller transitorisk (der så atter kan, men ikke behøver at forbinde sig med en deskriptiv eller normativ referenceramme).

Når der kan være grund til at fremhæve, at modernitet i sammenhængen her altid også har en temporalitetskvalitet ved sig, er grunden dobbelt. Således kan der anvendes modernitetsbestemmelser uden at det temporale egentlig spiller den afgørende rolle. Selv om temporalitet tilsyneladende er helt dominerende i reklamens indpiskning af modens »nu «, så er der dog som regel tale om en ren og skær temporalitetsfacade, der langt snarere end at referere til tiden udtrykker et signum på gentagelsestvangen, og dermed på atemporaliteten. Den emphatiske samtidighedsfornemmelse, som moden også kunne have, og som den ofte blev tillagt i den tidlige modernisme, er i dag reduceret til en kliché, der opløser, dvs. neutraliserer, samtidigheden til en seriel række af altid nu'er. Samtidigheden, der kunne være en mulighed, foregøgles her som den skinbarlige realitet. Reklamens mode rumsliggør tiden og reducerer moderniteten til Kitsch.

Der er imidlertid også et andet forhold, der nødvendiggør understregningen af, at modernitet i sammenhængen her altid er forbundet med et tidsaspekt. Temporalitetsmomentet vil nemlig ofte tilsyneladende være uudtalt eller kun indirekte til stede, fordi tiden aldrig viser sig som sådan, men kun i sine spor, altid ved noget andet. Dette er også grunden til, at modernitetsdiskussionen meget vel kan følges i en række vidensfelter, der ikke eksplicit handler om tiden, således f.eks. i kunsten, sociologien, hverdagslivsteorier.

Det blev hævdet, at modernitetsdiskussionen starter i den tidlige middelalder. Der kan dog være grund til at betone, at hele diskussionen måske kan inddeles i den gamle modernitetsdiskussion og den moderne modernitetsdiskussion. Sådan, at den simple ordidentitet ikke blokerer for iagttagelsen af det historisk særegne, men tvært imod udløser trangen til at se det variante og lade det invariante forblive en forstandig, men ikke fornuftig abstraktion. Den gamle modernitetsdiskussion er karakteristisk ved:

1) at modernitetsprædikatet alene forekommer i den deskriptive eller den epokalitetsmæssigt normative betydning (altså betydning 1 og 2 i Gumbrechts skema).

2) at den normative anvendelse af ordet så godt som altid forbinder sig med et dekadenceskema; enten i radikal »verden er af lave« betydning, eller mere afslappet i form af, at antikken antages at udgøre et forbillede, som det gælder om atter at tilnærme sig.

3 ) at den transitoriske betydning er fraværende.

4) at der aldrig tales om det moderne som sådant. Den prædikative brug af betegnelsen er enerådende. Hertil kommer så, at den prædikative 
brug oftest er relateret til relativt klart afgrænselige fænomener: kunst, videnskab etc., og sjældent finder anvendelse i forhold til så abstrakte størrelser som f.eks. tiden eller historien som sådan.

Den moderne modernitetsdiskussion er karakteristisk ved:

1) at modernitetsbetegnelsen anvendes i den deskriptive, den normative og den transitoriske betydning.

2) at der ikke primært opereres med et dekadenceskema, men hyppigst med et progres- eller udviklingsskema, når ordet anvendes normativt.

3) at udtrykket det moderne kan stå alene. Her er der således sket en markant abstraktificering.

4) at diskussionen udover at reflektere tiden og især samtiden også altid grundlæggende er reflekteret gennem et rationalitetskompleks. I den forstand er modernitetsdiskussionen en sammenrefleksion af temporalitet og rationalitet - og det er netop dette dobbeltmoment, der kundgør sig i den tiltagende abstraktificering, lige som det også er dette forhold, der implicerer at fra nu af er civilisations- og kulturkritik også altid fornuftskritik. Og omvendt: fornuftskritik har herefter altid civilisations- og kulturkritiske konsekvenser.

5) at der indfinder sig en iøjnefaldende tidsliggørelse af historien i den forstand, som Reinhart Koselleck bestemmer således:

»Siden anden halvdel af det 18. århundrede hober der sig talrige indicier op, der viser hen til begrebet for en ny tid i emphatisk forstand. Tiden forbliver ikke blot den form, som alle historier afspiller sig i, den får selv en historisk kvalitet. Det er ikke længere i tiden, men gennem tiden at historien fuldbyrdes. Tiden bliver dynamiseret til selv at være en historisk kraft « (»Vergangene Zukunft -zur Semantik Geschichtlicher Zeiten«, Frankfurt/M, 1979, s. 321).

Denne tidsliggørelse af historien var et basalt moment i såvel historicistiske som generelt evolutionære historiefilosofier. Men også op imod enhver historiefilosofisk prætention om ordning og kumulativ udvikling var og er tiden installeret som den moderne modernitetsdiskussions grundliggende tema. Om dette aflagde Marcel Proust vidnesbyrd på de sidste sider af »På sporet efter den tabte tid «, hvor han skrev: »Når der blot blev levnet mig tid nok til at fuldføre mit værk, ville jeg ikke undlade at mærke det med tidens segl, den forestilling, der i dag havde påtvunget sig mig med så megen styrke, og jeg ville deri skildre menneskene - om de så derved skulle komme til at ligne uhyrer - som optagende i tiden en uendelig større plads end den så indskrænkede, der er forbeholdt dem i rummet, en plads, der tværtimod er forlænget uden mål, eftersom de jo - som kæmper neddykkede i årene - på en gang rører ved vidt adskilte år og fjerne perioder, de har gennemlevet - hvor imellem så mange dage havde indordnet sig - i tiden «. 
De hidtidige overvejelser har skullet tjene til at lette og måske i det hele taget muliggøre spørgsmålet om »Marx og det moderne«, som der i det følgende vil blive taget stilling til.

\section{IV}

Ordet »moderne« især i den prædikative brug forekommer hyppigt i hele det Marxske forfatterskab, og moderniteten optræder som et helt afgørende problem i Marx' selvforståelse. Således er det ikke nogen tilfældighed, at han programmatisk udtaler, at »Kapitalens«

»yderste hensigt« er »at afsløre det moderne samfunds økonomiske bevægelseslov« (MEW 23, s. 15).

Inddeler man hans forfatterskab i tre faser - hvad der absolut kan være grund til at gøre uden at plausibiliteten heraf skal demonstreres her - så er det karakteristisk, at vi i de to første faser, altså fasen frem til 1845 og fasen fra 1845 til 1857, alene ser betegnelsen moderne anvendt prædikativt. Derimod begynder han i fasen efter at $\varnothing$ konomikritikken er indledt, dvs. efter at han er gået i gang med en kritik af den politiske $\varnothing$ konomis begreber snarere end en kritik af dens analyseresultater, at tale om det moderne som sådan.

I de tre faser er der tale om tre forskellige historiefilosofiske rammer for hans tænkning. Og ligeledes indgår ordet »moderne« i tre forskellige betydningskonstellationer.

1. fase. Her er den overordnede historiefilosofiske ramme spundet over et gammelkendt tema fra den okcidentale tænkning: oprindelig enhed - adskillende spaltethed - gentilegnet enhed. Temaet resumeres f.eks. $\mathrm{i} \gg$ De $\varnothing$ konomisk-filosofiske manuskripter«, når disse skal bestemme kommunismen:

»Kommunismen som positiv ophævelse af privatejendommen som menneskelig selvfremmedgørelse og derfor som virkelig tilegnelse af det menneskelige væsen gennem og for menneskene; derfor som menneskets fuldstændige, bevidste og indenfor den hidtidige udviklings hele rigdom tilbagevenden for sig som et samfundsmæssigt, dvs. som et menneskeligt menneske... Denne kommunisme ... er historiens opløste gåde, og den ved sig som denne løsning« (MEW Ergb. 1. del, s. 536).

Ordet moderne forekommer, men sjældent i nogen eksponeret eller analytisk afgørende betydning, og det optræder altid som prædikat.

2. fase. Her formuleres den materialistiske historieopfattelse, den senere såkaldte historiske materialisme, som Marx stikordsagtigt og programmatisk resumerede i »Forordet « til »Bidrag til kritik af den politiske økonomi « i 1859. Grundbegreberne er produktivkræfter, produktionsforhold, produktionsmåde, basis og overbygning. Konceptionen betjener sig i høj grad af en reformuleret oplysningsfilosofisk evolutionsmodel, og der opereres med historiske snit, som opstår på baggrund af produktivkræfternes udvikling i forhold til 
naturbeherskelsen og deres udvikling af samfundsmæssige forhold, der kan muliggøre produktivkræfternes bevægelsesformer (asiatisk, antik, feudal, kapitalistisk og kommunistisk produktionsmåde). Udviklingen udgår fra produktivkræfterne og tænkes at forløbe i et nødvendighedsskema.

Ved siden af denne inddelingsstruktur, forekommer der i den historiske materialisme også en anden, som især har interesse i sammenhægen her. Det drejer sig om en optik på hele den hidtidige historie, som inddeler denne $\mathrm{i}$ den gamle og den moderne historie. Her bruges betegnelsen moderne som en epokalitets bestemmelse. Den moderne historie udmærker sig ved flere forhold. Således f.eks.:

a) For første gang i historien kan klasserne afskaffes.

b) Menneskene kan for første gang trække sig ud af deres udleverethed til både naturen og deres egen samfundsmæssige organisering af overlevelsen.

c) For første gang kan menneskeheden, som det hedder »forlade sin egen forhistorie «.

Denne adskillelse mellem den gamle og den moderne historie kommer bl.a. og motivmæssigt vel dominerende - til udtryk i form af en antagelse om den moderne histories frembringelse af et revolutionsmæssigt novum:

»Ved alle hidtidige tilegnelser forblev en masse individer subsumeret under et eneste produktionsinstrument; ved proletarernes tilegnelse skal en masse produktionsinstrumenter subsumeres under hvert individ og under alles ejendom. Det moderne universelle samkvem kan ikke subsumeres på anden måde under individerne end derved, at det subsumeres under alle« (MEW 3, s. 68).

I den historiske materialisme er anvendelsen af betegnelsen »moderne « især karakteriseret ved at være en epokalitetsbestemmelse, der har sit faste forankringspunkt i det, hvorved det nye adskiller sig fra det gamle. Denne epokalitetsmæssige betydning af ordet moderne homogeniserer selv den hidtidige historie til den gamle historie, for i sig selv betragtet har den jo ingenlunde haft den entydighed, den nu tillægges i den moderne histories kontrastering til den.

3. fase. I fasen, hvor kritikken af den politiske økonomi er på programmet, sker der en interessant udbyggende relativering af den dyadiske epokalitetsbestemmelse, der henter sin identitet gennem den kontrasterende sammenstilling af den gamle og den moderne historie. Marx taler nu karakteristisk om »det moderne« som sådant - altså om ordet i den tredie betydning jvf. Gumbrechts skema.

I $\varnothing$ konomikritikken er der tale om mindst fire, ikke nødvendigvis hinanden udelukkende, forskellige historieordnende optikker:

1) Produktionsmådeinddelingen fra den materialistiske historieopfattelse bibeholdes, omend dens nødvendighedsparadigme ophæves. 
2) Der opereres med en tredeling af historien; en tredeling der bestemmes ud fra afhængighedsbegrebet, og som ikke er uden strukturligheder med den første fases brug af den okcidentale tænknings hyppigt anvendte skema (oprindelighed - adskillelse - gentilegnelse). Således hedder det i »Grundrisse « (pg. 75-76):

»Personlige afhængighedsforhold (oprindeligt helt naturgroede) er de første samfundsformer; her udvikles den menneskelige produktivitet kun i ringe omfang og på isolerede punkter. Personlig uafhængighed baseret på tingslig afhængighed er den anden store form, hvori der for første gang dannes et system af almindeligt, samfundsmæssigt stofskifte, af universelle relationer, alsidige behov og universelle evner. Fri individualitet baseret på individernes universelle udvikling og på underordningen af deres fælles samfundsmæssige produktivitet som deres samfundsmæssige formåen, er det tredie trin. Det andet trin skaber betingelserne for det tredie.«

Man ser her, at det andet trin kun skaber betingelserne for ikke nødvendigheden af det tredie trin. Altså også her er nødvendighedsparadigmet opgivet.

3) Marx viderefører endvidere den dyadisk epokale inddeling mellem den gamle og den moderne historie. Herom hedder det bl.a. i »Grundrisse (pg. 313):

»Således er det først kapitalen, der skaber det borgerlige samfund og den universelle tilegnelse af naturen såvel som af selve den samfundsmæssige sammenhæng gennem samfundets elementer. Deraf kapitalens store civiliserende indflydelse; dens produktion af et samfundstrin, over for hvilket alle tidligere kun fremtræder som menneskehedens lokale udviklinger og som naturidolatri. Først nu bliver naturen ren genstand for mennesket, en ren nyttighedssag; ophører med at være anerkendt som en magt for sig; og den teoretiske erkendelse af dens selvstændige love fremtræder selv blot som list for at underkaste dem under de menneskelige behov, det være sig som genstand for konsum eller det være sig som produktionsmiddel. Kapitalen driver ifølge denne sin tendens lige så meget ud over nationale skranker og fordomme, som ud over naturforgudelse og overleveret, indenfor bestemte grænser indhegnet tilfredsstillelse af forhåndenværende behov og reproduktion af gamle eksistensmåder. Den er destruktiv overfor alt dette, bestandigt revolutionerende, nedbrydende alle skranker, som hemmer produktivkræfternes udvikling, behovenes udvidelse, produktionens mangfoldighed og udnyttelsen af og byttet mellem natur-, og åndskræfterne«.

4) Ved siden af disse tre forskellige, men altså ikke nødvendigvis hinanden udelukkende, optikker på historien, og dermed placeringen af den moderne historie, findes der hos den sene Marx yderligere én, som er vigtig. Det er i forbindelse med denne, at han nu anvender ordet moderne som substantiv, idet der tales om »det moderne « som sådant. Moderniteten dybde- og breddepræger åbenbart de moderne samfund i deres differentierede mangfoldighed $\mathrm{i}$ en sådan grad, at der nu kan formuleres et almenbegreb, der udtrykker dette. 
Men, hvad er det moderne så karakteriseret ved, når det ikke længere primært henter sin identitet gennem en epokalitetsbestemmelse, der udtrykker en generel kontrast mellem de førmoderne og de moderne samfund?

I Marx' analyser er det moderne en konsekvens af kapitalens civiliserende indflydelse, som gør sig gældende i tredimensionaliteten:

a) menneskenes forhold til naturen.

b) menneskenes forhold til hinanden.

c) menneskenes forhold til sig selv.

Ifølge Marx er det dominerende moment for den civiliserende form for udvikling i tredimensionaliteten den kapitalistiske form for udvikling af produktivkræfterne. Det er herfra, der centrifugalt slynges effekter ud i de to andre dimensioner.

Som vist under punkt 3 , hvor den dyadiske epokalitetsbestemmelse i den $\varnothing$ konomikritiske fase blev fremhævet, er det således, at adskillelsen mellem den gamle og den moderne historie, og den heraf følgende homogenisering, selv bestemmes som en effekt af kapitalens civiliserende indflydelse. Bestemmelsen af kapitalens civiliserende indflydelse er dermed det, der ligger til grund for anvendelsen af modernitetsbetegnelsen i den epokale betydning. Pointen er nu, at overvejelserne omkring denne kapitalens rolle tillige fremtvinger nødvendigheden af et ikke epokalitetsmæssigt bundet betydningsindhold i det moderne.

På især to måder kommer kapitalens civiliserende indflydelse til udtryk: dels som måden, hvorpå traditioner erodes, og dels i måden, hvorpå udivklingen finder sted. Det fælles for begge er den blindhed, hvormed processen foregår. Ingen spørger om en tradition skal opgives, om gamle normer og former for livsudfoldelse egentlig bør erstattes af andre. Traditionsnedbrydningen finder sted som en naturhistorisk begivenhedsrække. Og netop herved reproduceres der i selve aftraditionaliseringen det moment, som ellers karakteriserede den traditionelle sammenhæng, nemlig, at den aldrig var til debat, men figurerede som en art transcendental ramme for livsudfoldelsen. Ligeledes er der tale om alt andet end entydighed omkring, hvor udviklingsprocessen egentlig fører hen, altså hvilket sigtepunkt der findes. Enhver påberåbelse af sikker viden om et synligt mål, har processen med ufravigelig styrke selv reduceret til pure ideologi, hvadenten denne så optræder som den liberale melioristiske fiktion om en udvikling henimod større og større lykke for flere og flere. Eller den tager form af en selvforblændende kommunistisk tillid til, at kapitalen af sig selv, med usvigelig sikkerhed og nødvendighed, fører til kommunisme - som man f.eks. med tragisk konsekvens troede, at Hitlers magtovertagelse alene ville være et opspeedende interregnum, der ville levere kommunismen på et fad kort tid efter hans magtovertagelse. 
I dette virvar af accellereret bevægelse og forandring indspundet $\mathrm{i}$ en mytisk gentagelsestvang og blindhed fremkommer der ganske vist en række irreversible fænomener. Således sker der en formal homogenisering af samfundsmæssige og menneskelige forskelle. Således indfinder der sig universelle standarder fra tandbørster, underbukser, fodtøj over seksuelle procedurer til moralske normer. Og således gøres livsrytmer tendentielt samtidige. Marx talte om, at rummet via kapitalens civiliserende indflydelse blev nedbrudt af tiden. I dag kan man tilføje, at dette tilsyneladende kun har fundet sted idet rummet som en anden fugl fønix har rejst sig af asken og rumsliggjort tiden.

På trods af disse irreversible fænomeners opkomst er det dog ikke uden betydning, at de tendenser og brud, de irreversible fænomener skulle udgøre substansen i, viser sig at være så godt som umulige at bestemme, hvis det ikke netop sker generaliserende kontrastivt: ikkenaturidolatri, ikke-bornert, ikke-naturudleverethed osv. $\mathrm{Nu}$ er det umuligt at bestemme noget alene via negatoriske bestemmelser. Men netop dette forhold er afgørende for det moderne. Ifølge Marx har det moderne således sin halve bestemmelse ved, hvad det negerer. Den anden halvdel er objektivt ubestemt. I den forstand er det moderne præget af en historisk frembragt kontingens, og denne kontingens er med til at give det moderne dets præg af at være noget flygtigt, transitorisk, hvor det, der forlades er lige så definitivt bestemmeligt og uigenkaldeligt, som det, der kommer er objektivt ubestemt.

Dette kontingensmoment - der ofte, ikke mindst i marxismens historie, substantielt og restløst er blevet gjort til inkarnationen af fremmedgørelsen - rummer vel, omend kun potentielt og endnu fanget i gentagelsestvangens tryllekreds, den forjættelse, som det moderne i al sin uforløsthed bærer. Var det mon ikke dette forhold, Marx havde i tankerne, da han i $»$ Grundrisse« skrev:

»Således forekommer den gamle anskuelse, hvor mennesket - i hvilken bornert national, religiøs, politisk bestemmelse, der end måtte gælde - optræder som produktionens formål, at være meget ophøjet i forhold til den moderne verden, hvor produktionen fremtræder som menneskets formål og rigdommen som produktionens formål. Men hvad er rigdommen, når den bornerte, borgerlige form afstrejfes, faktisk andet end den i det universelle bytte frembragte universalitet af behovene, individernes evner, nydelser, produktivkræfter etc.? Den fulde udvikling af det menneskelige herredømme over naturkræfterne, såvel i den såkaldte natur som i menneskets egen natur? Den absolutte udarbejdelse af dets skabende anlæg, uden anden forudsætning end den forudgående historiske udvikling, der gør denne udviklingens totalitet (dvs. totaliteten af udviklingen af alle menneskelige kræfter som sådanne, ikke målt ved en forud given målestok) til et mål i sig selv? Hvor det ikke reproducerer sig i en bestemthed, men producerer sin totalitet? Ikke søger at forblive et eller andet, der allerede er blevet til, men er i tilblivelsens absolutte bevægelse?«(Gr. s. 387). 
Hvad der her kaldes historisk frembragt kontingens, hvis samhørende bevidsthedsfigur da kan kaldes kontingensbevidsthed, er betingelsesmuligheden for fremkomsten af et forhold, hvor mennesket

»ikke søger at forblive noget, der er blevet til, men er i tilblivelsens absolutte bevægelse $\ll$.

Denne kontingens er ikke det samme som vilkårlighed, defineret som nødvendighedens fravær, men derimod fraværet af nødvendighedens refleksbestemmelse. Med andre ord er denne kontingens markeringen af brudchancerne i forhold til nødvendighedens og vilkårlighedens samhørende tryllekreds, det vil sige frihedens mulighed.

Marx opgav ikke den epokale modernitetsbestemmelse. Det gælder også i økonomikritikkens historieteoretiske overvejelser, at det kan være grund til at hævde et afgørende brud i menneskehedens historie omkring adskillelsen af den gamle og den moderne historie. Men netop økonomikritikkens afdækning af kapitalens civiliserende indflydelse og herunder opdagelsen af den historisk frembragte kontingens, implicerede en afgørende dæmpning af tilliden til den historiefilosofiske foregribelse af fremtiden. Og det betød også, at udviklings-nødvendighedsparadigmet måtte opgives. Hvilket der dog ikke er grund til at begræde som et offer: at en anden fremtid er mulig, ligger netop ved, at den ikke er nødvendig. Marx fulgte her Kant: frihedskausalitet kan ikke afledes af nødvendighedskausalitet. Eller med Marx' begreber: frihedens rige er ikke kalkuleret over emancipationsstrukturerne under nødvendighedens rige.

Og således er Marx' overvejelser omkring det moderne af en sådan beskaffenhed, at de har en dobbelteffekt på historiefilosofien i den historiske materialisme:

1) (hvad jeg ikke har været ret meget inde på her, men nok andre steder): ordningsbegreber og strukturer, der først bliver »praktisk sande « under kapitalismen kan ikke anvendes som andet end fællesbestemmelser (og altså ikke almenbestemmelser) i analysen af den prækapitalistiske historie.

2) Men tillige betyder opdagelsen af det modernes transitoriske karakter og herunder opdagelsen af den historisk frembragte kontingens, at historiefilosofien også må komme til kort, hvad angår fremtidens forudsigelighed.

Det var vel på baggrund af denne indsigt, at Marx i en note i Kapitalen med tilslutning kunne citere en vis G. Ortes, der skrev:

»I stedet for at opstille unyttige systemer for folkeslagenes lykke, vil jeg indskrænke mig til at unders $\varnothing$ ge grundene til deres ulykke« (MEW 23, s. 676, note 89). 